\title{
Origins and levels of artificial radionuclides within the Rhône river waters (France) for the last forty years: Towards an evaluation of the radioecological sensitivy of river systems
}

\author{
F. EYROLLE ${ }^{1}$, D. LOUVAT ${ }^{2}$, J.-M. MÉTIVIER ${ }^{3}$, B. ROLLAND ${ }^{1}$
}

(Manuscript received 1st February 2005, accepted 25 July 2005)

ABSTRACT The Rhône watershed extends over almost one hundred thousands square kilometers, i.e. one fifth of the metropolitan French territory. The Rhône is the major River entering the Western Mediterranean Sea as it generates the main source of sediments and freshwater $(50 \%)$ to the sea, with an average water discharge of $1700 \mathrm{~m}^{3} \mathrm{~s}^{-1}$. The River input affects primary production significantly in the northwestern Mediterranean area and plays a leading role on the marine ecosystem functioning in the whole Gulf of Lion. Almost twenty nuclear reactors are situated along the Rhône valley, representing Europe's biggest concentration of nuclear power plants. Down flow all these installations the spent fuel reprocessing plant of Marcoule released over many years most of the liquid radioactive wastes including plutonium isotopes in the Rhône river. Artificial radionuclides also originate from the weathering of the catchment basin labeled by both the global and the Chernobyl accident atmospheric fallout. These radioactive inputs have led to a permanent contamination of the Rhône river waters. Long-term chronological series of artificial radionuclide activities within the waters at the lower reaches of the Rhône river were acquired from 1979 to 2002 . These data give evidence for various radioecological responses of the aquatic system over years. Based on these observations several major radioecological sensitivity factors for river waters are identified.

Key words: Rhône river / artificial radionuclides / radioecological sensitivity / sediments / aquatic systems

RÉSUMÉ Origines et niveaux d'activités des radionucléides artificiels dans les eaux du Rhône (France) au cours des quarante dernières années : vers une évaluations de la sensibilité radioécologique des systèmes aquatiques continentaux de surface.

Le basin versant du Rhône s'étend sur près de $100000 \mathrm{~km}^{2}$, soit un cinquième du territoire français métropolitain. Le Rhône avec un débit moyen annuel de l'ordre de $1700 \mathrm{~m}^{3} \mathrm{~s}^{-1}$ est le fleuve principal de la mer Méditerranée occidentale apportant une partie considérable de sédiments et d'eau douce (50\%). Les apports de ce fleuve gouvernent la production primaire et le fonctionnement de l'écosystème marin dans l'ensemble du Golf du Lion. Près de vingt installations nucléaires sont implantées dans

\footnotetext{
IRSN, DEI/SESURE/LERCM, 13115 Saint Paul lez Durance, France.

IAEA, Waste Safety Section, P.O. Box 100, 1400 Vienna, Austria.

IRSN, DEI/SESURE/LME, 13115 Saint Paul lez Durance, France.
} 


\begin{abstract}
la vallée rhodanienne. La vallée est ainsi le siège de l'une des plus fortes concentrations d'industries nucléaires en Europe. Durant de nombreuses années, l'usine de retraitement du combustible irradié de Marcoule a représenté le terme source prépondérant de radioactivité artificielle pour les eaux du Rhône avec notamment des rejets liquides en isotopes du plutonium. La radioactivité artificielle observée dans le fleuve provient également du drainage des sols de son bassin versant marqué par les retombées des tirs et de l'accident de Tchernobyl. Ces apports ont conduit à une contamination quasi permanente des eaux du Rhône mais évolutive. Des séries chronologiques sur les activités en radionucléides artificiels sur la période de 1979 à 2002 permettent de mettre en évidence diverses réponses du système aquatique rhodanien au cours du temps et de définir un certain nombre de facteurs de sensibilité radioécologique pour les eaux de surface du milieu aquatique continental.
\end{abstract}

\title{
1. Introduction
}

The Rhône watershed extends over one hundred thousands square kilometers, i.e. one fifth of the metropolitan French territory. The Rhône river exports about fifty billions cubic meters of water and several millions tons of solid matter per year towards the Mediterranean sea. The Rhône river is the most important river of France by the mean annual stream flow $\left(1700 \mathrm{~m}^{3} \mathrm{~s}^{-1}\right)$ and the major river entering the western Mediterranean sea as it generates the main source of particles and freshwater $(50 \%)$ to this marine environment. Despite extensive damming, its discharge is still subject to important short-term variations, even at the daily scale. Besides the role of seasonal snow melting, these variations often result from the frequent occurrence of localized storms of Mediterranean origin, falling onto various areas of the lower watershed, where the geological basement changes from crystalline to sedimentary rocks. Due to important industrial and agricultural activities, and a high population density, strong anthropogenic influences might be expected. The River input affects primary production significantly in the northwestern Mediterranean area and plays a leading role on the marine ecosystem functioning in the whole Gulf of Lion.

Almost twenty nuclear reactors are situated along the Rhône valley, representing Europe's biggest concentration of nuclear power plants. Until 1997, the whole nuclear fuel cycle was represented by the facilities that lay along the Rhône valley. In compliance with the legislation, these industries were allowed to release low activity liquid effluent into the Rhône river. Down flow all these installations the spent fuel reprocessing plant of Marcoule released most of the liquid radioactive wastes (Charmasson, 1998). Furthermore, radioactive isotopes observed in the Rhône river also originate from the weathering of the catchment basin labeled by the global atmospheric fallout from the past nuclear tests carried out between 1945 and 1980 and the atmospheric fallout from the Chernobyl accident that occurred on 24 April 1986 (Cigna et al., 1987; Thomas, 1996; Calmet et al., 1998; Renaud et al., 1999). 
Long-term radioecological series (1979-2002) on artificial radioactivity within the waters of the lower course of the Rhône river underline the radioecological response of the river system submitted to almost 60 years of contamination of various source terms and levels. These results are used for identifying some major radioecological sensitivity factors for river waters.

\section{Material and method}

An empirical two-box model was used to calculate the particulate fluxes of cesium and plutonium isotopes from the soils of the Rhône basin towards the Rhône river through erosion/alteration processes. This model uses at a one year scale atmospheric cumulative deposits on the whole Rhône watershed and solid matter flow rates at the lower course of the River as reported in Noël (1996), Thomas (1996) and Duffa (2001). Regarding cesium isotope fluxes towards the Rhône river, atmospheric cumulative cesium deposits were calculated using the model of Mitchell et al. (1990) and the mean annual rainfall on 650 stations of MétéoFrance and from Renaud et al. (2004). Activities within the liquid releases from the Marcoule plant were obtained from Charmasson (1998) until 1996 and from the COGEMA reports until 2002 (Levy, 1996-2002). Long-term chronological series of artificial radionuclide activities were acquired since the seventies within the Rhône valley environmental compartments in the frame of environmental survey, monitoring or specific research studies. Various water fractions were analyzed over years depending on the sampling objectives: unprocessed water, dissolved or particulate fraction obtained from sedimentation or filtration using various filter type or porosity. These data were extracted from the SYLVESTRE IRSN data base.

\section{Results and discussion}

\subsection{Characterization of artificial radioactivity source terms}

\subsubsection{Watershed erosion}

Soil erosion/leaching generates water and solid matter fluxes and associated contaminants toward river systems. Part of artificial radionuclides observed in the Rhône river was introduced through the washing out of the draining basin marked by first the global fallout from the past nuclear atmospheric tests then the atmospheric fallout from the Chernobyl accident that occurred on 24 April 1986 (Fig. 1). During the most intensive period regarding nuclear tests, i.e. between 1961 and 1964, the releases within the atmosphere were estimated to $200 \mathrm{EBq}$ $\left(200 \times 10^{18} \mathrm{~Bq}\right)$ for fission products and 5 tons for plutonium isotopes. These inputs 


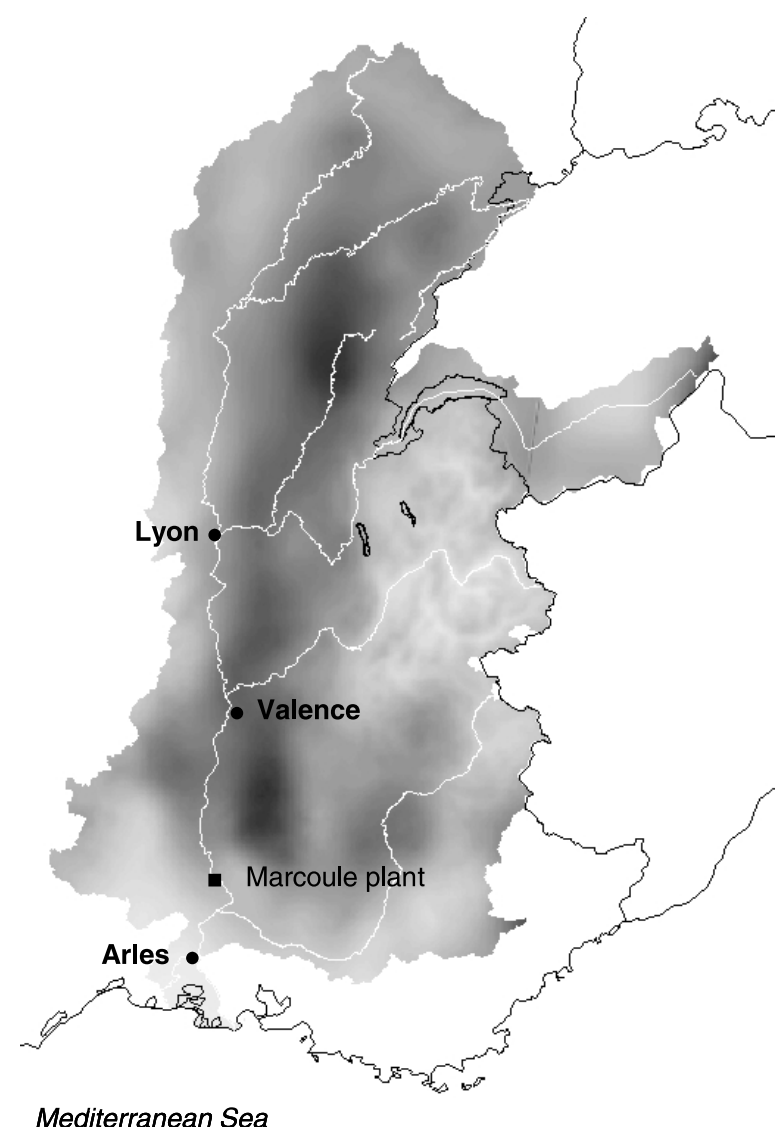

Mediterranean Sea

40000

Figure $1-{ }^{137}$ Cs residual activities in 2004 from atmospheric deposits (global fallout + Chernobyl) over the Rhône basin (in Bq $\mathrm{m}^{-2}$ ).

Activités résiduelles en ${ }^{137}$ Cs dans les sols du basin versant du Rhône en 2004 (en Bq m ${ }^{-2}$ ).

led to a global contamination of the atmosphere that decreased over years but is still detectable nowadays mainly in the north hemisphere regarding the long half live radionuclides. Atmospheric fallout led to continuous contamination of soils over many years. In France, the mean residual activities in soils are estimated $2000 \mathrm{~Bq} \mathrm{~m}^{-2}$ for ${ }^{137} \mathrm{Cs}, 50 \mathrm{~Bq} \mathrm{~m}^{-2}$ for ${ }^{239+240} \mathrm{Pu}$ and $1.5 \mathrm{~Bq} \mathrm{~m}^{-2}$ for ${ }^{238} \mathrm{Pu}$.

The Chernobyl accident released about $2 \mathrm{EBq}$ of fission products for some few days that led to contamination of soils of part of Europe. Contaminated air masses 
passed over the eastern part of France April 30th and May 5th. In the lower Rhône valley, two rainfall events occurred during this period, on May 3rd and 4th. The East part of France where the Rhône watershed extends was submitted to 1250 to $40000 \mathrm{~Bq} \mathrm{~m}$ of additional ${ }^{137} \mathrm{Cs}$ mainly due to the rain that fold during the passage of the Chernobyl plume (Renaud et al., 1999). No plutonium isotopes fallout from the Chenobyl accident was identified in the country. Between 1964 and $1985,{ }^{137} \mathrm{Cs}$ inputs from the watershed decreased from 400 to $55 \mathrm{GBq} \mathrm{y}^{-1}$. In 1986 , the ${ }^{137} \mathrm{Cs}$ washing out from the soils to the river was estimated to $2000 \mathrm{GBq}$ as a mean annual value. That year, generally the ${ }^{137} \mathrm{Cs}$ terrestrial input reached the ${ }^{137} \mathrm{Cs}$ released by Marcoule (Fig. 2). This is based on mean annual values as the model lays it down. The pulse of contamination that may occurred the days following the fallout is not attainable. Nowadays, after fifteen years, ${ }^{137} \mathrm{Cs}$ terrestrial inputs are estimated to reach $100 \mathrm{GBq}^{-1}$, i.e. more than before the accident.

\subsubsection{Reprocessing plant liquid releases}

Since 1961, the Marcoule reprocessing plant represented the main source term of alpha, beta and gamma emitters of industrial origin along the Rhône valley. First mainly dedicated to military spent fuel reprocessing, the plant came in an industrial spent fuel reprocessing for the seventies. Due to a change in the liquid effluent treatment process in 1990, liquid releases drastically decreased by 1 to 2 order of magnitude. Therefore at the year scale, ${ }^{239+240} \mathrm{Pu}$ amounts released by Marcoule reached the ${ }^{239+240} \mathrm{Pu}$ contribution from the watershed erosion and ${ }^{137} \mathrm{Cs}$ industrial inputs became lower than those originating from the soils leaching.

In 1997, the reprocessing plant started a dismantlement plan that led to a new significant decrease for most of radionuclides. The chronological accounts of artificial radionuclides input in the Rhône river are shown in Figure 2. The composition of the liquid effluents varied within a wide range over years. An example is given for 2000 in Figure 3.

\subsection{Artificial radioactivity measured in the Rhône river waters}

\section{${ }^{137}$ Cs and ${ }^{134}$ Cs chronological series}

Figure 4 presents the data relating to ${ }^{137} \mathrm{Cs} /{ }^{134} \mathrm{Cs}$ activity ratios observed in waters at the lower course of the Rhône river over years. Since the end of the nineties no detectable ${ }^{134} \mathrm{Cs}$ is observed in the waters even though several cubic meters of waters are concentrated and analyzed. 


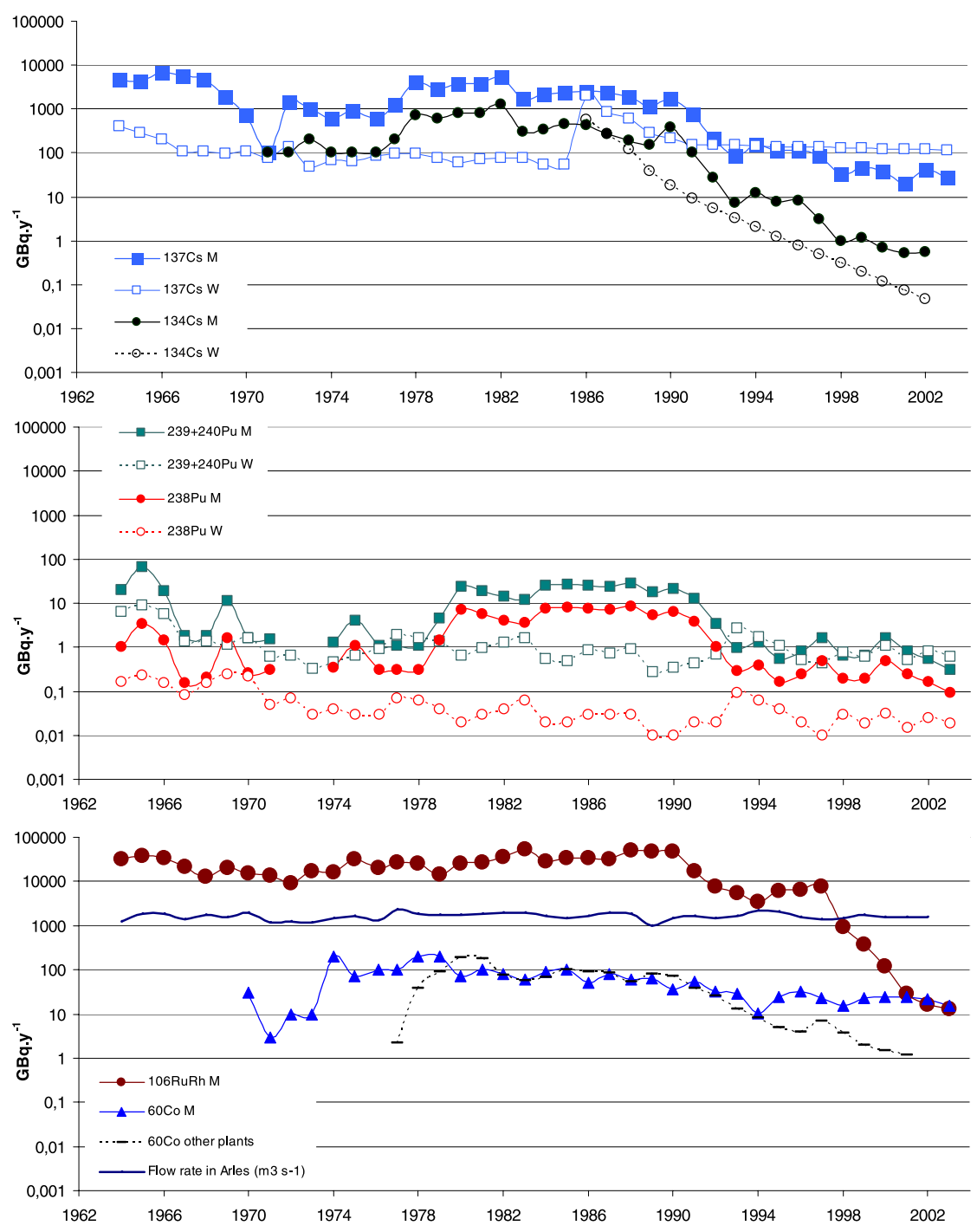

Figure 2 - Chronological account of some artificial radionuclides released by the Marcoule reprocessing plant $(M)$ or originating from the watershed soil erosion $(W)$.

Chronologie des apports de quelques radionucléides rejetés par le centre de retraitement de Marcoule (M) ou issus du drainage des sols du basin versant (W). 


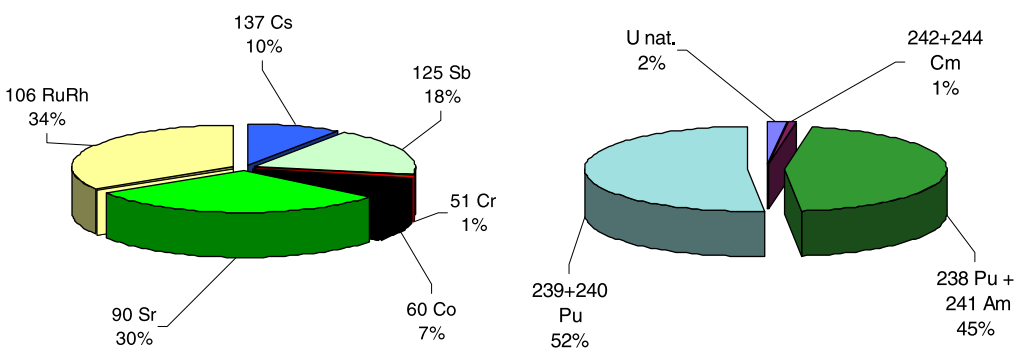

Figure 3 - Mean isotopic composition of $\beta, \gamma$ (except tritium) and $\alpha$ emitters of Marcoule liquid effluents in 2000.

Composition isotopique moyenne en émetteurs $\beta, \gamma$ (hors tritium) et $\alpha$ des rejets liquides de Marcoule en 2000.

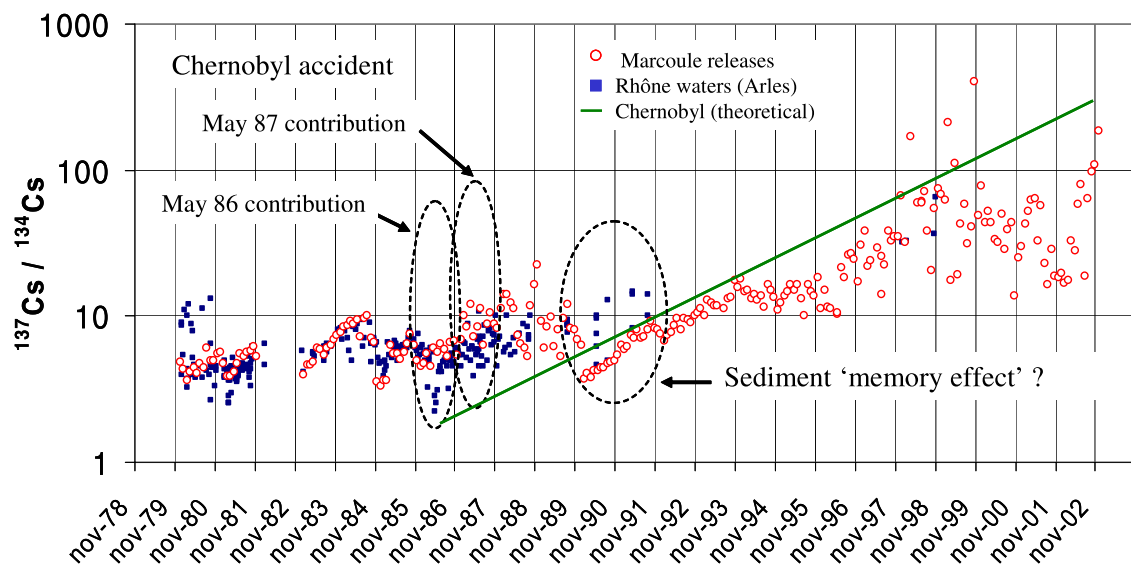

Figure $4-{ }^{137} \mathrm{Cs} /{ }^{134} \mathrm{Cs}$ activity ratios within the waters of the lower course of the Rhone river downstream of Marcoule.

Rapports d'activité ${ }^{137} \mathrm{Cs} /{ }^{134} \mathrm{Cs}$ dans les eaux de la partie terminale du Rhône en aval de Marcoule.

All available data originating from different water fractions were used here as isotopes of a same element behave in a single way. The results show generally a Marcoule isotopic signature in waters as activity ratios observed over years are similar to those characterizing Marcoule liquid effluents with some exceptions in 1986, 1987 and 1990-1992. Indeed the relationship between the ${ }^{137}$ Cs activities measured in waters (whole fraction) and the Marcoule releases shows significant high activities in 1986, 1987, 1990 and from 1997 to 2002 (Fig. 5a). This means 


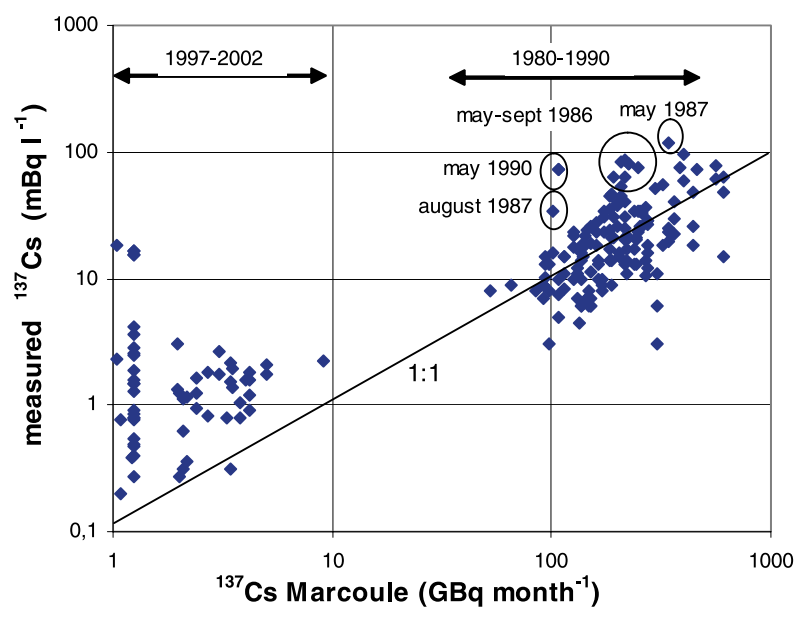

(a)

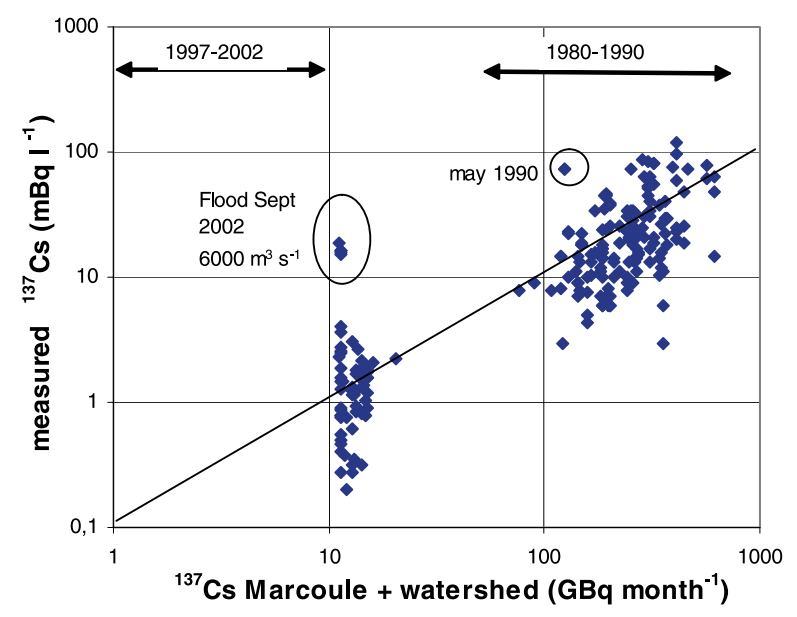

(b)

Figure 5 -Measured ${ }^{137}$ Cs activities in waters (whole fraction) at the lower course of the Rhône river downstream of the Marcoule reprocessing plant as a function of Marcoule liquid releases (a) and both Marcoule liquid releases and watershed contribution (b).

Activités en ${ }^{137}$ Cs mesurés dans les eaux du Rhône (fraction entière) en aval de Marcoule en fonction des rejets (a) et en fonction à la fois des rejets et des apports du bassin versant (b). 
that during these periods of time the Marcoule liquid releases were not the main source term for the river waters. The results show that the contribution of the watershed was significant in 1986, 1987 and generally from 1997 to 2002 with key exceptions in 1990 and the 1997-2002 period during high river flow rates (Fig. 5b).

What can we learn from these results in the frame of radioecological sensitivity of river system purpose?

\subsection{Aquatic system response to accidental atmospheric fallout}

In May $1986,{ }^{137} \mathrm{Cs} /{ }^{134} \mathrm{Cs}$ activity ratios observed in waters drastically decreased from 6 to 2.5 . The ${ }^{137} \mathrm{Cs} /{ }^{134} \mathrm{Cs}$ activity ratio characterizing the Chernobyl fallout was 2 in 1986 and reaches 100 nowadays. Following the Chernobyl accident, the lower course of the Rhône River was contaminated mainly by the Chernobyl fallout on its watershed. From April 23rd to the middle of May important rainfalls furthered both atmospheric deposits on soils and leaching from the soils to the river. From the relationship obtained in the Figure 5a and based on ${ }^{137} \mathrm{Cs}$ measured in waters from May to September 1986 (60 to $87 \mathrm{mBq}^{-1}$ ) we can estimate that almost $1000 \mathrm{GBq}$ per month of ${ }^{137} \mathrm{Cs}$ reached the River through soil leaching waters. This input may represent about $0.3 \%$ of the atmospheric deposits on the soils of the whole watershed. The response was very fast as on may 5 th, the first available data point after the Chernobyl accident, the ${ }^{137} \mathrm{Cs} /{ }^{134} \mathrm{Cs}$ activity ratio was already 2.2 and the ${ }^{137} \mathrm{Cs}$ activities 5 fold higher than the one measured at the beginning of April. On spring 1987, low ${ }^{137} \mathrm{Cs} /{ }^{134} \mathrm{Cs}$ activity ratios underline an increasing contribution of the watershed contaminated by the Chernobyl accident (Fig. 4) probably due to snow melting from mountainous massif that were shown to be particularly submitted to atmospheric fallout (Cigna et al., 1987; Calmet et al., 1998; Pourcelot et al., 2003).

Our results underline that the Rhône river received less than $0.5 \%$ of accidental atmospheric fallout occurring on its draining basin during the 3 months following the accident. Seasonal pulse inputs may occur during the following years depending on the origin of waters.

Watershed surface, soil erosion rate, typology variability, rainfall intensity and occurrence, water origin may represent key radioecological sensitivity factors for river systems regarding accidental atmospheric fallout.

\subsection{Aquatic system response to drastic decrease of primary industrial sources}

In 1990, the Marcoule liquid releases drastically decreased and ${ }^{137} \mathrm{Cs} /{ }^{134} \mathrm{Cs}$ activity ratios varied from 12 (August 1989) to 3.7 (January 1990). The few 
available data acquired between May 1990 and November 1991 show unexpected high ${ }^{137} \mathrm{Cs} /{ }^{134} \mathrm{Cs}$ activity ratios varying from 6 to 12 (Fig. 4). The measured ${ }^{137} \mathrm{Cs}$ activities in waters are almost 1 order of magnitude higher than the ones expected with respect to both the Marcoule and watershed inputs (Fig. 5b). This unexpected signature has to be related to a sedimentary source term contribution, i.e. a sediment 'memory effect'. Cesium is known to be a particle reactive element that fix on suspended material and may be temporary stored within sediment beds. Sedimentary storages and associated contaminants may represent a delayed source term for river waters. This delayed source term may act through diffusion processes and/or remobilization processes that occur during flood events. Regarding plutonium isotopes, that are high particle reactive elements, Eyrolle et al. (2002, 2004) and Lansard et al. (2003) showed that remobilization from contaminated sedimentary deposits may contribute up to $30 \%$ of the water activity during floods. Neither particular flood events nor high flow rates were registered when sampling in 1990-1991. This may emphasize the role of diffusion processes from sedimentary beds to the water column. The ${ }^{137} \mathrm{Cs} /{ }^{134} \mathrm{Cs}$ activity ratios measured from may 1990 to the end of 1991 underline that the contribution of antecedent contaminated sedimentary deposits to the water activity represented the main source term. Nevertheless, the lack of data after 1991 does not allow an estimation of the long term impact of such a delayed source term.

Sedimentary storages, sedimentary dynamic and residence time, fluvial geomorphology are major parameters in the frame of an investigation of the longterm radioecological sensitivity of river systems.

\subsection{Aquatic system response to extreme events}

On September 2002, the flow rate of the River drastically increased from $800 \mathrm{~m}^{3} \mathrm{~s}^{-1}$ to more than $10000 \mathrm{~m}^{3} \mathrm{~s}^{-1}$ in $24 \mathrm{~h}$ due to exceptional rainfall that arose in the 'Cévenole' part of the Rhône watershed. This Cévenole event consistently occurs when well-known meteorological conditions are combined. The ${ }^{137} \mathrm{Cs}$ measured in the waters during the highest flow rates of the River show significant differences from the expected ones (Fig. 5b). Flood events may lead to water contamination pulses through remobilization of antecedent contaminated sedimentary storages. Nevertheless, important rainfall on contaminated areas may also emphasize contamination from the soils to the river and act as contamination pulses. The empirical erosion model used gives mean fluxes at a one year-scale and does not reflect chronicle fluxes from the watershed that may occur during factual meteorological events. 
The consequences of extreme events such as important rainfall or floods on the contamination transfer have to be evaluated as they may lead to significant increases in contaminant levels temporarily and/or locally.

\section{Conclusions}

Long-term radioecological series on artificial radioactivity within the waters of the lower course of the Rhône river underline the radioecological responses of the river system submitted to almost 60 years of contamination of various source terms and levels. These data underline the relative impact of primary sources such as accidental atmospheric fallout or industrial low activity liquid releases on river waters. Besides, sedimentary storages were shown to generate delayed source terms of contamination for waters through chemical diffusion or/and physical remobilization processes that may significantly act after drastic decreases of primary sources and during flood events. This study underlines that the watershed surface, soil erosion rate, typology variability, rainfall intensity and occurrence, water origin, sedimentary storages, sedimentary dynamic and residence time, fluvial geomorphology, flood intensity and occurrence are key parameters in the frame on an investigation of the radioecological sensitivity of River systems at a short or longer term.

\section{REFERENCES}

Calmet D., Bouisset P., Goutelard F., Market E., Barescut J.C. (1998) Résultats de mesures de la radioactivité des sols CRII-RAD, Rapport IPSN/DPRE 98-30.

Charmasson S. (1998) Cycle du combustible nucléaire et milieu marin, Devenir des effluents rhodaniens en Méditerranée et des déchets immergés en Atlantique Nord-Est, Thèse d'État, Université Aix-Marseille II, Rapport CEA-R-5826, Gif/Yvette, France, 359 p.

Cigna A.A., Roosi L.C., Sgorbini S., Zurlini G. (1987) Environmental study of fallout plutonium in soils from the Piemonte Region (North-West Italy), J. Environm. Rad. 5, 71-81.

Duffa C. (2001) Répartition du plutonium et de l'américium dans l'environnement de la basse vallée du Rhône, Thèse de l'université d'Aix Marseille III, 179 p.

Eyrolle F., Arnaud M., Duffa C., Renaud Ph. (2002) Plutonium fluxes from the Rhône river to the Mediterranean Sea, Radioprotection 37 (C1), 87-92.

Eyrolle F., Charmasson S., Louvat D. (2004) Plutonium isotopes in the lower reaches of the river Rhône over the period 1945-2000: Fluxes towards the Mediterranean Sea and sedimentary inventories, J. Environm. Rad. 74, 127-138.

Lansard B., Charmasson S., Eyrolle F., Arnaud M., Grenz C. (2003) Plutonium isotope remobilisation from natural sediments (Gulf of Lions, Northwestern Mediterranean Sea): Estimate from flume experiments, Plutonium Future, The Science Conference, Albuquerque, New Mexico USA, July 6-10, 2003

Lévy F. (1996-2002) Contrôle des rejets du Site, Comptes Rendu Technique, Rapports COGEMA Marcoule. 
Mitchell P.I., Sanchez-Cabeza J.A., Ryan T.P., McGarry A.T., Vidal-Quatras A. (1990) Preliminary estimates of cumulative caesium and plutonium deposition in the Irish terrestrial environment, J. Radioanal. Nucl. Chem. 138, 241-256.

Noël M.H. (1996) Le plutonium traceur du transfert et de l'accumulation des apports particulaires du Rhône en Méditerranée Nord Occidentale, Thèse de l'université Paris XII-Val de Marne, France, $256 \mathrm{p}$.

Pourcelot L., Louvat D., Gauthier-Lafaye F., Stille P. (2003) Formation of radioactivity enriched soils in mountain areas, J. Environm. Rad. 68, 215-233.

Renaud Ph., Beaugelin K., Maubert H., Ledenvic Ph. (1999) Les retombées en France de l'accident de Chernobyl, Conséquences radioécologiques et dosimétriques, EDP Science, Les Ulis.

Renaud Ph., Métivier J.M., Castelier E., Pourcelot L., Louvat D. (2004) Cartographie des dépôts de ${ }^{137} \mathrm{Cs}$ en mai 1986 sur l'ensemble du territoire français métropolitain, Radioprotection 39, 23-38.

Thomas A.J. (1996) Input of artificial radionuclides to the Gulf of Lions and tracing the Rhône influence in marine surface sediments, Deep-Sea Res. 44, 577-595. 